\title{
Prenatal Diagnosis of $\beta$-thalassemia with Cell-free Fetal DNA in Maternal Plasma
}

\author{
Lijian Zhao', Xuxia Liang1, Haini Huang4, Huihua Lan², Xin Wu³ and Chenhong Wang5
}

\begin{abstract}
The aim of this study was to explore the feasibility of non-invasive prenatal genetic diagnosis of $\beta$-thalassemia with small fragments of cell-free fetal DNA (cffDNA) in peripheral blood of pregnant women. It was an observational study carried out at Department of Obstetrics, The People's Hospital of Guangxi Zhuang Autonomous Region, Nanning, Guangxi, China, from January 2016 to March 2018. A total of 40 pregnant women, who were likely to give birth to babies with severe $\beta$-thalassemia, were selected, and $\beta$-globin genotype of the fetus was non-invasively detected by cffDNA in peripheral blood of their mothers. Small fragments of cffDNA from all specimens were successfully amplified. Compared with the results of traumatic prenatal diagnosis, 37 cases $(92.50 \%)$ were diagnosed and 3 cases $(7.50 \%)$ were misdiagnosed. The cffDNA in maternal plasma can be used for non-invasive prenatal genetic diagnosis of $\beta$-thalassemia, and is worthy of promotion.
\end{abstract}

Key Words: Cell-free fetal DNA (cffDNA), $\beta$-thalassemia, Non-invasive, Prenatal genetic diagnosis.

$\beta$-thalassemia is a hereditary hemolytic anemia caused by $\beta$-globin gene mutation and a decrease or lack of $\beta$-globin chain synthesis. ${ }^{1}$ The typical clinical feature of this disease is small cell hypochromic anemia with increased $\mathrm{HbF}$ and/or $\mathrm{HbA}^{2}$ At present, prenatal diagnosis of beta thalassemia gene is an effective method to prevent the birth of babies with severe $\beta$-thalassaemia. At present, the clinical diagnosis of $\beta$-thalassemia is mainly based on invasive methods. A safe, effective, and accurate non-invasive prenatal detection method can greatly reduce the burden on as well as protect the health of pregnant women.

The discovery of cell-free fetal DNA (cffDNA) in maternal blood plasma has provided a new idea for non-invasive prenatal detection. The cffDNA is generated, mainly by apoptosis of trophoblast cells or placental cells, and marginally by fetal blood circulation or fetal cells. Maternal plasma cffDNA is detectable at week-5 of pregnancy and reaches a maximum of two during the last eight weeks of pregnancy. The cffDNA in maternal

1 Department of Obstetrics / Laboratory Medicine 2 / Prenatal Diagnosis Center ${ }^{3}$, The People's Hospital of Guangxi Zhuang Autonomous Region, Nanning, Guangxi, China

4 Prenatal Diagnosis Center, Affiliated Hospital of Youjiang Medical University for Nationalities, Baise, Guangxi, China

5 Department of Obstetrics and Gynecology, Maternal and Child Healthcare Hospital of Shenzhen City, Southern Medical University, Shenzhen, China

Correspondence: Dr. Chenhong Wang, Department of Obstetrics and Gynecology, Maternal and Child Healthcare Hospital of Shenzhen City, Southern Medical University, Shenzhen, 518000, China

E-mail: syd548@163.com

Received: August 28, 2018; Accepted: November 22, 2018 peripheral blood has a half-life as short as about 16 minutes, and is rapidly cleared in the body of the mother within too hours after delivery. Therefore, detection with cffDNA is highly specific. Lo et al. confirmed that it is completely feasible to use cffDNA for fetal gene detection. ${ }^{3}$

The aim of this study was to explore the feasibility of noninvasive prenatal genetic diagnosis of $\beta$-thalassemia with small fragments of cffDNA in peripheral blood of pregnant women.

This study was carried out at Department of Obstetrics, The People's Hospital of Guangxi Zhuang Autonomous Region, Nanning, Guangxi, China, from January 2016 to March 2018. A total of 40 pregnant women, who were likely to give birth to babies with severe $\beta$-thalassemia, were selected as subjects. Inclusion criteria were women without abnormal pregnancy history, B-ultrasound confirmed as single fetus survival, and both husband and wife were genetically diagnosed as carriers of betathalassemia. Women with clinical diagnosis of pregnancy complications and comorbidities were excluded. The study was approved by the Hospital ethics committee and all subjects signed informed consent.

Conventional invasive prenatal diagnosis of $\beta$-thalassemia was performed by taking pregnant women's villi or amniotic fluid. In addition, $10 \mathrm{ml}$ of peripheral blood of pregnant women was collected and anticoagulated with ethylenediaminetetraacetic acid (EDTA), and cffDNA was extracted for non-invasive prenatal diagnosis of $\beta$-thalassemia. The main method was PCR reaction, which was performed on a PCR machine. Under the PCR reaction, the corresponding $\beta$-globin gene fragment was amplified, and by amplifying the primer sequence, all primers were labeled with biotin at the $5^{\text {th }}$ end. Total volume of small fragments of cffDNAs 
Table I: Results of 7 specimens with the same parental genotype.

\begin{tabular}{|c|c|c|c|c|c|}
\hline Specimen number & Mother genotype & Father genotype & Fetal genotype & CffDNA genotype & $\begin{array}{c}\text { Whether consistent with } \\
\text { the results of traumatic } \\
\text { prenatal diagnosis }\end{array}$ \\
\hline 1 & $-28 \mathrm{M} / \mathrm{N}$ & $-28 \mathrm{M} / \mathrm{N}$ & $-28 \mathrm{M} / \mathrm{N}$ & $-28 \mathrm{M} / \mathrm{N}$ & Yes \\
\hline 2 & $41-42 \mathrm{M} / \mathrm{N}$ & $41-42 \mathrm{M} / \mathrm{N}$ & $41-42 \mathrm{M} / 41-42 \mathrm{M}$ & $41-42 M / 41-42 M$ & Yes \\
\hline 3 & $41-42 \mathrm{M} / \mathrm{N}$ & $41-42 \mathrm{M} / \mathrm{N}$ & $41-42 \mathrm{M} / \mathrm{N} \mathrm{N} / \mathrm{N}$ & $41-42 \mathrm{M} / \mathrm{N} 41-42 \mathrm{M} / \mathrm{N}$ & Yes \\
\hline 4 & $41-42 \mathrm{M} / \mathrm{N}$ & $41-42 \mathrm{M} / \mathrm{N}$ & $41-42 \mathrm{M} / 41-42 \mathrm{M}$ & $41-42 \mathrm{M} / 41-42 \mathrm{M}$ & Yes \\
\hline 5 & $41-42 \mathrm{M} / \mathrm{N}$ & $41-42 \mathrm{M} / \mathrm{N}$ & $41-42 \mathrm{M} / \mathrm{N}$ & $41-42 \mathrm{M} / \mathrm{N}$ & Yes \\
\hline 6 & $41-42 \mathrm{M} / \mathrm{N}$ & $41-42 \mathrm{M} / \mathrm{N}$ & $\mathrm{N} / \mathrm{N}$ & $\mathrm{N} / \mathrm{N}$ & Yes \\
\hline 7 & $41-42 \mathrm{M} / \mathrm{N}$ & $41-42 \mathrm{M} / \mathrm{N}$ & $\mathrm{N} / \mathrm{N}$ & $41-42 \mathrm{M} / \mathrm{N}$ & No \\
\hline
\end{tabular}

$M=$ Mutation, $N=$ Wild type.

in the peripheral plasma of pregnant women was $50 \mu \mathrm{l}$, measured with secondary PCR method, and the template solution was $2 \mu \mathrm{l}$ of the initial PCR product. The other methods were the same as the initial PCR reaction system. The reaction conditions were: pre-denaturation for 5 minutes at $95^{\circ} \mathrm{C}$; denaturation for 30 seconds at $94^{\circ} \mathrm{C}$; renaturation for 30 seconds at $56^{\circ} \mathrm{C}$; extension for one minute at $72^{\circ} \mathrm{C}$ for 40 cycles. The product was stored at $4^{\circ} \mathrm{C}$ in the $2 \%$ agarose gel, $5 \mu \mathrm{l}$ of the PCR product was subjected to electrophoresis, EB staining and gel imaging analysis. The $\beta$-globin gene was determined with membrane reverse hybridization. A transmembrane hybrid $\beta$-thalassemia gene diagnostic kit and 24 probes were used to simultaneously detect 17 kinds of mutated genes commonly found in the Chinese population, i.e., CD17 A>T, CD41/42 (-TTTC), 28>G, and IVS-II-654 C>T, etc., and operations were conducted strictly according to the kit instructions. The blue spots appearing on the dot blot membrane were observed. If the probe detected a color intensity at the mutation and a blue spot appeared adjacent to its corresponding wild-type probe, the locus was identified as a heterozygote of gene mutation and the wild type; if the probe detected blue spots on the mutation, and no blue spots were found in the corresponding wild type, the locus was identified as a homozygous mutation; if the probe detected the corresponding wild type and there appeared a corresponding blue spot, the sample to be tested was determined to be free of the above 17 gene mutations. Percentages and frequencies were calculated for various qualitative variables. Mean and standard deviations were calculated for different quantitative variables.

The 40 pregnant women were from 22 to 34 years, with an average age of $27.95 \pm 1.64$ years; their gestational weeks were 10 to 22 , with an average gestation of 15.78 \pm 1.21 weeks. Of the 40 specimens, $7(17.50 \%)$ had the same parental genotype and $33(82.50 \%)$ had different parental genotypes.

The cffDNA of all specimens were subjected to secondary PCR reaction, and the amplified region was clearly observed by agarose gel electrophoresis. All small fragments of cffDNA were successfully amplified.

Compared with the results of traumatic prenatal diagnosis, 37 cases $(92.50 \%)$ of non-invasive detection of cffDNA in peripheral blood were diagnosed, and three cases $(7.50 \%)$ were misdiagnosed. The seven cases with the same parental genotype were analysed, and the diagnose accordance rate was $85.71 \%$ ( 6 cases), one case $(14.29 \%)$ of the normal fetus was misdiagnosed as a $\beta$-thalassemia gene carrier, as shown in Table I.

The 33 specimens with different parental genotypes were analysed, and the diagnose accordance rate was $93.94 \%$ ( 31 cases), two cases $(6.06 \%)$ of $\beta$-thalassemia gene carriers was misdiagnosed as patients with severe $\beta$-thalassemia.

Compared with invasive prenatal diagnosis such as chorionic villus sampling, cffDNA-based non-invasive prenatal detection requires only the collection of maternal peripheral blood to directly analyse the fetal genetic material, reducing the harm to the mother and the fetus. In addition, it has the characteristics of early screening and short detection period. 4

Reverse dot blot (RDB) is a relatively simple and economical method for detecting $\beta$-thalassemia gene mutations. One experiment can simultaneously detect the more common 17 gene mutations in Chinese. This study used RDB technique to detect cffDNA, showing that $37(92.50 \%)$ cases were diagnosed and three $(7.50 \%)$ cases were misdiagnosed compared with the traumatic prenatal diagnosis. The reason for the misdiagnosis of these 3 cases is mainly abnormal hybridisation resulted from the infection of maternal DNA. It can be seen that the use of cffDNA for noninvasive prenatal genetic diagnosis of $\beta$-thalassemia can achieve good results, but there are also some defects. The conclusions of this study are basically consistent with the results of Xiong et al. ${ }^{5}$ Limited by the operating technology and funding, this study only includes a small number of samples from pregnant women with severe $\beta$-thalassemia in China. Sample size may continue to be expanded in the future to compare the differences with samples from the Western population and further verify the accuracy of the results.

This study shows that cffDNA in maternal plasma can be used for non-invasive prenatal genetic diagnosis of betathalassemia. The technique is easy to take samples and has broad clinical application prospects with no risk to pregnant women and fetuses. 


\section{REFERENCES}

1. Traivaree $\mathrm{C}$, Monsereenusorn $\mathrm{C}$, Rujkijyanont $\mathrm{P}$, Prasertsin $\mathrm{W}$, Boonyawat B. Genotype-phenotype correlation among betathalassemia and beta-thalassemia/ $\mathrm{HbE}$ disease in Thai children: Predictable clinical spectrum using genotypic analysis. J Blood Med 2018; 9:35-41.

2. Birch L, English CA, O'Donoghue K, Barigye O, Fisk NM, Keer JT. Accurate and robust quantification of circulating fetal and total DNA in maternal plasma from 5 to 41 weeks of gestation. Clin Chem 2005; 51:312-20.
3. Lo, YM, Chiu RW. Noninvasive approaches to prenatal diagnosis of hemoglobinopathies using fetal DNA in maternal plasma. Hematol oncol Clin North Am 2010; 24:1179-86.

4. Mackie FL, Hemming K, Allen S, Morris RK, Kilby MD. The accuracy of cell-free fetal DNA-based non-invasive prenatal testing in singleton pregnancies: A systematic review and bivariate meta-analysis. BJOG 2017; 124:32-46.

5. Xiong L, Barrett AN, Hua R, Tan TZ, Ho SS, Chan JK, et al. Non-invasive prenatal diagnostic testing for $\beta$-thalassaemia using cell-free fetal DNA and next generation sequencing. Prenat Diagn 2015; 35:258-65. 